\title{
An Analytical Study of Fish Consumption in Egypt
}

\author{
Nagwa M. El-agroudy, Fatima A. Shafiq, Soheir Mokhtar and Monia Bahaa El- Din \\ Hassan
}

Department of Agricultural Economy, Agricultural and Biological Research Division, National Research Centre, 33 El Buhouth St., (Former El Tahrir St.) 12622 Dokki, Giza, Egypt

Received: 20 August 2019/ Accepted 15 Oct. 2019/ Publication date: 25 Oct. 2019

\begin{abstract}
Fish is conspicuously an important source of necessary food sources for the construction of the human body because it is one of animal protein sources necessary for maintaining human health and safety. Besides, fish is characterized by its easily digestion and absorption and synthesis compared to the protein found in red meat and poultry meat. This is in addition to containing fatty acids necessary for the protection of human from heart and circulation diseases.Moreover, Egypt suffers from a deficit in animal protein and low production average per Individual's Share compared to the world average. The average of animal protein per individual in the world was about $27.5 \mathrm{~kg}$ per year, while in Egypt it did not reach half of this rate because there are many problems that limit expanding the production of red meat and poultry meat, including the limited agricultural area, thus intensifying competition on main crops such as wheat and feed crops. This is in addition to the deficit in the concentrated feed production, where most livestock production requirements are imported from abroad.Consequently, the development of fish production is one of the pillars of the development of animal protein sources in Egypt, where the Egyptian fish production increased from about 649 thousand tons in 2000 to about 1870 thousand tons in 2018 with an increasing rate reached about $188 \%$ and with a production average of 1205.2 thousand tons during the period 2000-2018.
\end{abstract}

Keywords: fish Production, fish Consumption, fish consumption , function.

\section{Problem of the Study}

The problem of this study is the low productivity of the majority of Egyptian fisheries, despite the large number and variety of fish farms suitable for fishing in Egypt, namely, seas, lakes, low coasts, River Nile, its branches and fisheries with its different types. The area of these fisheries is about 13.6 million acres, and the fish gap is estimated at 117.7 thousand tons as an average for the period (2000-2018).

\section{Objective of the Study}

The research aims to study the demand for fish in Egypt through examining the development of production and consumption capacity, average per Individual's share and fish self-sufficiency ratio in Egypt. This is in addition to studying the determinants of fish Consumption function in Egypt.

\section{Methodology and Data Sources of the Study}

The study depends on the descriptive analysis approach to describe the research data, and the quantitative analysis approach through using some mathematical and statistical methods such as estimating equations of general time trend in the linear image, using multiple regression model in estimating the consumption function of fish in Egypt. Besides, this research depends on published and unpublished data of the Central Agency for Public Mobilization and Statistics.

\section{Results of the Study}

First: Development of Fish Production in Egypt

The data shown in Table (1) concerning the development of fish production capacity in Egypt indicated that there was a significant gradual increase in fish production during the period (2000-

Corresponding Author: Nagwa M. El-agroudy, Department of Agricultural Economy, Agricultural and Biological Research Division, National Research Centre, 33 El Buhouth St., (Former El Tahrir St.) 12622 Dokki, Giza, Egypt. 
2018), ranging from a minimum of 649 thousand tons in 2000 to a high of about 1870 thousand tons in 2018 , with an increase of $188.1 \%$ compared to its counterpart in 2000 . Besides, the fish gap size was estimated by about173.3 thousand tons during the study period, with a self-sufficiency ratio of $86.5 \%$ during the study period.

Equation No. (1) in Table (2) Shows that production has taken an annually and statistically significant increasing trend amounted to about 64.986 thousand tons, which represents about $5 \%$ of the average period of study.

Table 2: Development of some fish production and consumption Indicators in the Arab Republic of Egypt during the period (2000-2018)

\begin{tabular}{|c|c|c|c|c|c|}
\hline Years & $\begin{array}{c}\text { Quantity of } \\
\text { Production } \\
\text { (thousand } \\
\text { tons) }\end{array}$ & $\begin{array}{c}\text { Quantity of } \\
\text { Consumption } \\
\text { (thousand tons) }\end{array}$ & $\begin{array}{c}\text { Average per } \\
\text { Individual's } \\
\text { Share(kg) }\end{array}$ & $\begin{array}{c}\text { Self -sufficiency } \\
(\%)\end{array}$ & $\begin{array}{c}\text { Gap } \\
\text { (thousand tons) }\end{array}$ \\
\hline 2000 & 649 & 886 & 14 & 73 & -237 \\
\hline 2001 & 772 & 950 & 14.5 & 81.3 & -178 \\
\hline 2004 & 865 & 1064 & 15.3 & 81.3 & -199 \\
\hline 2005 & 889 & 075 & 15.2 & 82.7 & -186 \\
\hline 2006 & 971 & 1173 & 6.2 & 82.8 & -202 \\
\hline 2007 & 1008 & 1225 & 16.6 & 82.3 & -217 \\
\hline 2008 & 1085 & 1151 & 15.3 & 94.3 & -66 \\
\hline 2012 & 1372 & 1605 & 12.6 & 85.5 & -233 \\
\hline 2013 & 1454 & 1653 & 12.6 & 88.9 & -181 \\
\hline 2014 & 1482 & 1704 & 12.8 & 87 & -222 \\
\hline 2015 & 1519 & 1707 & 12.5 & 89 & -188 \\
\hline 2016 & 1706 & 1894 & 13.5 & 90.1 & -188 \\
\hline 2017 & 1820 & 1930 & 12.8 & 94.3 & -110 \\
\hline 2018 & 1870 & 1980 & 12.6 & 94.4 & -110 \\
\hline Average & 1205.2 & 1379 & 14.04 & 86.5 & -173.3 \\
\hline
\end{tabular}

Food Gap = Production - Consumption

Self-sufficiency $=($ Production $/$ Consumption $) \times 100$

Source: Central Agency for Public Mobilization and Statistics, Annual Bulletins of Livestock Statistics

\section{Second: Development of Fish Consumption in Egypt}

Table (1) shows a gradual increase in fish consumption, where consumption ranged between a minimum limit of about 886 and a maximum limit of about 1980 thousand tons in 2000-2018, respectively, with an increase of about 123.5 compared to its counterpart in 2000. Equation No. (2) In Table (2) Illustrated that consumption has taken an annually and statistically significant growing trend amounted to about 63.705 thousand tons, representing about $4.62 \%$ of the average period of study.

\section{Third: Development of the Individual's Share Average of Fish in Egypt}

Table (1) Shows that there is a gradual decrease in the average per individual of fish, where consumption ranged between the minimum of about 12.2 and the maximum of about $16.6 \mathrm{~kg} /$ year in 2007 and 2010 respectively, and an average of the study period of about $14.04 \mathrm{~kg} /$ year. Equation No. (3) In Table (2) that the average per Individual's Share has taken a general trend decreasing and statistically significant amounted to about $1.65 \mathrm{~kg} /$ year, which represents about $11.75 \%$ of the average of the study period

\section{Fourth: Development of Self-Sufficiency Ratio of Fish in Egypt}

Table (1) shows a gradual increase in the self-sufficiency rate of fish, where the ratio ranged between a minimum of about $73 \%$ and a maximum of about $94.4 \%$ in $2000-2018$, respectively. Equation No. (4) in table (2) Shows that the percentage of fish self-sufficiency has taken an increasing 
statistically significant annual trend amounted to about $0.711 \%$ annually representing about $0.82 \%$ of the average of the study period.

Table 2: Equations of the general time trend of fish production and consumption indicators in Egypt

\begin{tabular}{cllccc}
\multicolumn{2}{c}{$(2000-2018)$} & & & \\
\hline Equation & The Dependent Variable & Equation & T & F & R \\
\hline $\mathbf{1}$ & Production Quantity & $\mathrm{Yi}=555.351+64.986 \mathrm{Xi}$ & $25.484^{* *}$ & 600.47 & 0.974 \\
$\mathbf{2}$ & Amount of Consumption & $\mathrm{Yi}=742.684+63.705 \mathrm{Xi}$ & $23.614^{* *}$ & 557.63 & 0.985 \\
$\mathbf{3}$ & Average per Individual's Share & $\mathrm{Yi}=15.637-1.65 \mathrm{Xi}$ & $-2.936^{*}$ & 9.690 & $0 . .580$ \\
$\mathbf{4}$ & Self-sufficiency (\%) & $\mathrm{Yi}=-79.414+0.711 \mathrm{Xi}$ & $4.771^{* *}$ & 22.762 & 0.757 \\
$\mathbf{5}$ & Amount of Food Gap & $\mathrm{Yi}=-186.070-1.296 \mathrm{Xi}$ & 0.668 & 0.446 & 0.468 \\
\hline
\end{tabular}

i.Y: the estimated value of the dependent variable in year

i.Xi: time variable per year

i: $1,2,3, \ldots \ldots 19$

** Significant at 0.01

* Significant at 0.05

Source: calculated from data of table no. (1).

\section{Fifth: Development of the Food Gap of Fish in Egypt}

Table (1) shows that there is a gradual increase in the amount of the fish gap, ranging from a minimum of about 66 thousand tons in 2008 and a maximum of about 370 thousand tons in 2011 with an increase of $460.6 \%$ compared to its counterpart in 2008. Equation No. (5) in Table (2) Shows that the gap of fish has taken a general trend of decreasing statistically insignificant amounted to about 1.296 thousand tons representing about $0.75 \%$ of the average of the study period.

\section{Sixth: Fish Consumption Function in Egypt}

Through studying the relationship between fish consumption in Egypt in thousand tons as an independent variable $\left(\mathrm{y}_{\mathrm{i}}\right)$, fish prices $(\mathrm{x} 1)$, red meat prices $(\mathrm{x} 2)$, poultry prices $(\mathrm{x} 3)$ perlkg, the annual individual income by pound (x4) and the population by million people (x5) as independent variables during the period 2000-2018. Thus, it was possible to estimate the consumption function of the fish in the logarithmic form. The model was formulated in the following mathematical form:

$$
\operatorname{LnY}_{\mathrm{i}}=\mathrm{a}+\mathrm{b} 1 \operatorname{Ln} x 1_{\mathrm{i}}+\mathrm{b} 2 \operatorname{Lnx} 2_{\mathrm{i}}+\mathrm{b} 3 \operatorname{Ln} x 3_{\mathrm{i}}+\mathrm{b} 4 \operatorname{Ln} \mathrm{x} 4_{\mathrm{i}}+\mathrm{b} 5 \operatorname{Ln} \times 5_{\mathrm{i}}
$$

Through estimating the model using the Multiple Regression Analysis approach in the logarithmic form during the study period, the following equation shows the significance of the impact of $x 5$ (population) on the quantity of fish consumption in Egypt. Moreover, the results indicate that a change of $1 \%$ in the population leads to an increase in the consumption of fish by about 0.826 thousand tons. According to the value of the modified determinant variable $\mathrm{R}^{\prime 2}$, the independent factors represented in the function are responsible for about $97 \%$ of the changes in the quantity available for fish consumption. It is also found that the value of (F) is about 143.946, which is statistically significant.

$\operatorname{Ln} Y_{i}=2.525-0.067 \operatorname{Ln} X 1_{i}+0.022 \operatorname{Ln~X} 2_{i}+0.181 \operatorname{Ln~X} 3_{i}+0.073 \operatorname{Ln~X} 4_{i}$

$(1.435) \quad(-1.203)(0.688)(0.901)(0.649)$

$+0.827 \mathrm{Ln} \mathrm{x} 5_{\mathrm{i}}$

* (2.415)

$\mathrm{R}^{2}=0.975$

$\mathrm{F}=143.946$

Conducting the Step-wise Regression between the amount of fish consumption in Egypt and the previously mentioned independent factors in the logarithmic form was to address the problems of econometrics, namely, linear duplication, self-correlation and heterogeneity. Besides, the simple correlation coefficient matrix was performed between the amount of fish consumption and influencing independent variables in order to make sure of all previous influences treatment. The result is as follows: 
$\mathrm{Ln} \mathrm{Yi}=2.705+0.280 \mathrm{Ln}$ xi $3+0.867 \mathrm{LnX} 5 \mathrm{i}$

$$
\begin{aligned}
& (2.056) \quad(3.711)^{* *} \quad(2.808)^{* *} \\
& \mathrm{R}^{\prime 2}=0.988 \\
& \mathrm{~F}=286.677
\end{aligned}
$$

The results of this model indicate the significant impact of the variable, $\mathrm{X} 3, \mathrm{x} 5$ on the amount of fish consumption in Egypt, where a population increase of $1 \%$ leads to an increase in fish consumption by 0.867 thousand tons. Moreover, the increase in the price of poultry by $1 \%$ leads to an increase in fish consumption by 0.280 thousand tons. The value of the determination coefficient indicates that the variables of population and poultry prices in this model are responsible for $98 \%$ of the changes in the quantity of fish consumption in Egypt.

Table 3: Average per individual's share and real prices of red and white meat and fish in Egypt during the period (2000-2018)

\begin{tabular}{rcccccc}
\hline Years & $\begin{array}{c}\text { Amount of } \\
\text { Consumption/ } \\
\text { thousand tons }\end{array}$ & $\begin{array}{c}\text { Red Meat } \\
\text { Prices }\end{array}$ & $\begin{array}{c}\text { White Meat } \\
\text { Prices/ } \\
\text { Poultry } \\
\text { Meat }\end{array}$ & $\begin{array}{c}\text { Fish } \\
\text { Prices }\end{array}$ & $\begin{array}{c}\text { Individual's } \\
\text { Income Per } \\
\text { Month }\end{array}$ & $\begin{array}{c}\text { Number of } \\
\text { Population / } \\
\text { Million } \\
\text { People }\end{array}$ \\
\hline $\mathbf{2 0 0 0}$ & 886 & 16.99 & 6.37 & 6.53 & 416.5 & 63.305 \\
$\mathbf{2 0 0 1}$ & 950 & 17.09 & 5.96 & 6.57 & 437.5 & 64.652 \\
$\mathbf{2 0 0 2}$ & 932 & 17.93 & 6.83 & 10.7 & 459.25 & 65.986 \\
$\mathbf{2 0 0 3}$ & 1015 & 21.08 & 6.85 & 10.87 & 516.83 & 67.383 \\
$\mathbf{2 0 0 4}$ & 1064 & 25.46 & 8.69 & 13.08 & 589.08 & 68.648 \\
$\mathbf{2 0 0 5}$ & 1075 & 27.30 & 8.06 & 13.3 & 641.08 & 69.997 \\
$\mathbf{2 0 0 6}$ & 1173 & 27.63 & 9.33 & 13.59 & 721.5 & 71.348 \\
$\mathbf{2 0 0 7}$ & 1225 & 33.99 & 10.37 & 15.00 & 923.42 & 72.940 \\
$\mathbf{2 0 0 8}$ & 1151 & 45.81 & 13.19 & 16.42 & 1078.33 & 74.439 \\
$\mathbf{2 0 0 9}$ & 1264 & 39.81 & 13.84 & 18.37 & 1217.92 & 76.099 \\
$\mathbf{2 0 1 0}$ & 1481 & 39.75 & 15.96 & 20.12 & 1357.5 & 77.840 \\
$\mathbf{2 0 1 1}$ & 1526 & 51.64 & 17.96 & 21.77 & 1433.33 & 79.618 \\
$\mathbf{2 0 1 2}$ & 1605 & 58.31 & 17.34 & 24.77 & 1512.5 & 81.567 \\
$\mathbf{2 0 1 3}$ & 1653 & 62.16 & 20.83 & 28.6 & 1583.33 & 83.667 \\
$\mathbf{2 0 1 4}$ & 1704 & 67.74 & 24.41 & 30.33 & 1683.83 & 85.783 \\
$\mathbf{2 0 1 5}$ & 1707 & 88.88 & 25.97 & 32.24 & 1785.58 & 78.963 \\
$\mathbf{2 0 1 6}$ & 1894 & 99.63 & 25.77 & 33.76 & 1885.58 & 90.086 \\
$\mathbf{2 0 1 7}$ & 1930 & 100.56 & 29.42 & 34.33 & 1918.1 & 92.115 \\
$\mathbf{2 0 1 8}$ & 1980 & s110.22 & 32.14 & 36.53 & 1998.36 & 96.278 \\
\hline
\end{tabular}

Source: Central Agency for Public Mobilization and Statistics -Counted and Compiled from the Statistical Annual BookVarious Editions

\section{Summary and Recommendations}

Fish is conspicuously an important source of necessary food sources for the construction of the human body because it is one of animal protein sources necessary for maintaining human health and safety. Besides, the study aims to shed light on fish production capacity in Egypt from its various sources and estimate fish consumption in Egypt.

It has been shown, through studying the relative importance of fish production in Egypt from its various sources, that fish production average in Egypt reached about 1205.5 thousand tons during the period $(2000-2018)$. The consumption average and the individual's share average of fish were about 1379 thousand tons and $14.04 \mathrm{~kg}$ / year respectively during the study period. Additionally, the average of self-sufficiency ratio and fish gap during the same period were about $86.5 \%$ and 173.3 thousand tons respectively.

It becomes obviously clear from the estimation of fish consumption in Egypt during the period (2000 - 2018) that there is a statistically significant correlation between the quantity of fish consumption and the price of poultry and the population.

Therefore, the study recommends the need to expand fish farming due to its importance in bridging fish food gap as a result of the steady increase in the population as shown in the study. 


\section{References}

Abdul Majeedm A., 1990 Lectures in Agricultural Statistics. Department of Agricultural Economics, Faculty of Agriculture, Assiut University.

Central Agency for Public Mobilization and Statistics - Statistical Annual book - Various Editions.

Hammad, H. A. and K. Amal, 2014. Economic Analysis of the Demand of Red and White Meat and Fish in Egypt. Egyptian Journal of Agricultural Economics, $24^{\text {th }}$ Volume, $4^{\text {th }}$ Edition, December.

Iman, M. B. and S. A. Iman, 2014. An Economic Study of Fish Production and its Problems in Egypt. The Egyptian Journal of Agricultural Economics, $24^{\text {th }}$ Volume, $1{ }^{\text {st }}$ Edition, March. 